\title{
Formation of hydroxyl radical from San Joaquin Valley particles extracted in a cell-free surrogate lung fluid
}

\author{
H. Shen and C. Anastasio \\ Department of Land, Air and Water Resources, University of California, Davis, One Shields Avenue, Davis, CA 95616, USA
}

Received: 6 May 2011 - Published in Atmos. Chem. Phys. Discuss.: 16 June 2011

Revised: 7 September 2011 - Accepted: 9 September 2011 - Published: 20 September 2011

\begin{abstract}
Previous studies have suggested that the adverse health effects from ambient particulate matter (PM) are linked to the formation of reactive oxygen species (ROS) by $\mathrm{PM}$ in cardiopulmonary tissues. While hydroxyl radical $\left({ }^{\bullet} \mathrm{OH}\right)$ is the most reactive of the ROS species, there are few quantitative studies of $\bullet \mathrm{OH}$ generation from PM. Here we report on ${ }^{\bullet} \mathrm{OH}$ formation from PM collected at an urban (Fresno) and rural (Westside) site in the San Joaquin Valley (SJV) of California. We quantified ${ }^{\bullet} \mathrm{OH}$ in PM extracts using a cell-free, phosphate-buffered saline (PBS) solution with or without $50 \mu \mathrm{M}$ ascorbate (Asc). The results show that generally the urban Fresno PM generates much more ${ }^{\bullet} \mathrm{OH}$ than the rural Westside PM. The presence of Asc at a physiologically relevant concentration in the extraction solution greatly enhances ${ }^{\bullet} \mathrm{OH}$ formation from all the samples. Fine PM $\left(\mathrm{PM}_{2.5}\right)$ generally makes more ${ }^{\bullet} \mathrm{OH}$ than the corresponding coarse PM ( $\mathrm{PM}_{\mathrm{cf}}$, i.e. with diameters of 2.5 to $\left.10 \mu \mathrm{m}\right)$ normalized by air volume collected, while the coarse PM typically generates more ${ }^{\bullet} \mathrm{OH}$ normalized by $\mathrm{PM}$ mass. ${ }^{\bullet} \mathrm{OH}$ production by SJV PM is reduced on average by $(97 \pm 6) \%$ when the transition metal chelator desferoxamine (DSF) is added to the extraction solution, indicating a dominant role of transition metals. By measuring calibration curves of ${ }^{\bullet} \mathrm{OH}$ generation from copper and iron, and quantifying copper and iron concentrations in our particle extracts, we find that PBSsoluble copper is primarily responsible for ${ }^{\bullet} \mathrm{OH}$ production by the SJV PM, while iron often makes a significant contribution. Extrapolating our results to expected burdens of PMderived ${ }^{\bullet} \mathrm{OH}$ in human lung lining fluid suggests that typical daily PM exposures in the San Joaquin Valley are unlikely to result in a high amount of pulmonary ${ }^{\bullet} \mathrm{OH}$, although high PM events could produce much higher levels of ${ }^{\bullet} \mathrm{OH}$, which might lead to cytotoxicity.
\end{abstract}

\section{Correspondence to: C. Anastasio} (canastasio@ucdavis.edu)

\section{Introduction}

Epidemiological studies have shown strong correlations between the exposure to ambient particulate matter (PM) and adverse human health outcomes such as pulmonary and cardiovascular diseases and premature deaths (Dockery et al., 1993; Pope et al., 1995, 2004; Pekkanen et al., 2002; Pope and Dockery, 2006). One suggested mechanism by which PM induces toxic effects is PM-mediated oxidative stress and cell damage through the generation of reactive oxygen species (ROS) such as superoxide $\left({ }^{\bullet} \mathrm{O}_{2}^{-}\right)$, hydrogen peroxide $(\mathrm{HOOH})$, and hydroxyl radical $\left({ }^{\circ} \mathrm{OH}\right)(\mathrm{Li}$ et al., 2008 ; Valavanidis et al., 2008; Gonzalez-Flecha, 2004; Donaldson et al., 2003). These ROS are thought to be formed in the cell during oxidative phosphorylation, where sequential electron addition to dissolved $\mathrm{O}_{2}$ results in the formation of ${ }^{\bullet} \mathrm{O}_{2}^{-}$, $\mathrm{HOOH}$, and ${ }^{\bullet} \mathrm{OH}$, respectively (Li et al., 2003). As shown in Fig. 1, ROS can also be formed via reduction of oxygen species by the reduced forms of transition metals, which are recycled via reductants such as ascorbate.

$\cdot \mathrm{OH}$ is the most reactive ROS and it can react with most organic molecules at diffusion-controlled rate constants (Held et al., 1996; Forman et al., 2010). Unlike ${ }^{\bullet} \mathrm{O}_{2}^{-}$and $\mathrm{HOOH}$, which can be detoxified by superoxide dismutase and catalase, respectively, ${ }^{\bullet} \mathrm{OH}$ cannot be eliminated enzymatically. ${ }^{\bullet} \mathrm{OH}$ can cause a variety of oxidative damage to cellular macromolecules including carbohydrates, lipids, proteins, and nucleic acids, which can result in cell death and disease (Valavanidis et al., 2008; Kell, 2010). Thus in vitro and in vivo ${ }^{\circ} \mathrm{OH}$ formation might be useful as an indicator of the toxic potential of inhaled PM (Cohn et al., 2008). The generation of ${ }^{\bullet} \mathrm{OH}$ from particles extracted in cell-free solutions also gives information about the oxidative potential of $\mathrm{PM}$. Several groups have made these types of ${ }^{\bullet} \mathrm{OH}$ measurements, both for ambient particles as well as specific types of particles (Shi et al., 2003; Baulig et al., 2004; Kunzli et al., 2006; Jung et al., 2006; Alaghmand and Blough, 2007;

Published by Copernicus Publications on behalf of the European Geosciences Union. 


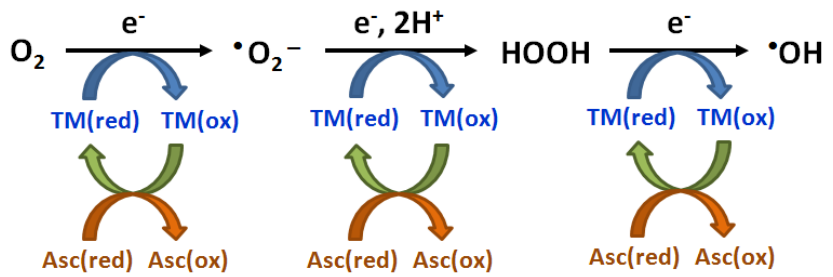

Fig. 1. Transition-metal-catalyzed production of reactive oxygen species. TM represents transition metals, Asc is ascorbate, and (red) and (ox) represent reduced and oxidized forms. In this scheme, reduced forms of transition metals donate electrons to convert dissolved molecular oxygen to, sequentially, superoxide, hydrogen peroxide, and hydroxyl radical, with the reductant ascorbate (Asc) serving as the ultimate electron donor.

DiStefano et al., 2009; Vidrio et al., 2009). These studies indicate the amounts of $\bullet \mathrm{OH}$ that can be chemically generated by different particles, and generally find that transition metals play the dominant role in ${ }^{\bullet} \mathrm{OH}$ generation.

Transition metals such as $\mathrm{Fe}$ and $\mathrm{Cu}$ are common components of PM that can produce ROS - both directly via chemical reactions and indirectly via inflammatory cell activation causing oxidative stress, inflammation, mutagenesis and cell proliferation, which can result in cardiopulmonary diseases and cancer (Kennedy et al., 1998; Jimenez et al., 2000; Hetland et al., 2000; Prahalad et al., 1999; Ghio et al., 1999; Knaapen et al., 2002; Donaldson et al., 2003; Schaumann et al., 2004). The general importance of transition metals is illustrated by the fact that PM-mediated ROS production and related cellular damage can be inhibited by the metal chelator desferoxamine mesylate (DSF) (Donaldson et al., 1997; Prahalad et al., 2001; Alaghmand and Blough, 2007; Vidrio et al., 2009; Shen et al., 2011). Previous studies have also shown that $\mathrm{Fe}$ and $\mathrm{Cu}$ appear to be the most important particulate transition metals for making ROS (Donaldson et al., 1997; Vidrio et al., 2008, 2009; Shi et al., 2003; DiStefano et al., 2009; Wang et al., 2010; Shen et al., 2011; Nawrot et al., 2009).

To help characterize the chemical generation of ROS from ambient particles in a cell-free solution, we recently measured the formation of $\mathrm{HOOH}$ by fine $\left(\mathrm{PM}_{2.5}\right)$ and coarse $\left(\mathrm{PM}_{\mathrm{cf}}\right)$ particles collected at an urban and rural site in the San Joaquin Valley (SJV) of California (Shen et al., 2011). In this current manuscript we report measurements of ${ }^{\bullet} \mathrm{OH}$ on these same SJV particles, in order to: (1) quantify the amounts of $\bullet \mathrm{OH}$ produced from the particles in the same surrogate lung fluid; (2) compare ${ }^{\bullet} \mathrm{OH}$ generation from PM samples collected at the urban and rural site, during different seasons (summer vs. winter), and in different sizes (fine vs. coarse); (3) explore the role of added ascorbate on ${ }^{\bullet} \mathrm{OH}$ generation; and (4) examine the role of transition metals in general, and $\mathrm{Cu}$ and $\mathrm{Fe}$ in particular, in ${ }^{\bullet} \mathrm{OH}$ formation.

\section{Materials and methods}

\subsection{Chemicals}

Ascorbic acid (Asc, $\geq 99.0 \%$ ), chelex-100 sodium form resin, copper (II) sulfate $\left(\mathrm{CuSO}_{4} 5 \mathrm{H}_{2} \mathrm{O}, 98+\%\right.$, A.C.S. reagent grade), desferoxamine mesylate (DSF, 95\% TLC), and ferrous sulfate $(99.9+\%)$ were from Sigma. Acetonitrile $\left(\mathrm{CH}_{3} \mathrm{CN}\right)$, nitric acid $\left(\mathrm{HNO}_{3}\right.$, Optima), perchloric acid $\left(\mathrm{HClO}_{4}\right.$, Optima), potassium phosphate monobasic $\left(\mathrm{KH}_{2} \mathrm{PO}_{4}\right.$, HPLC grade), sodium benzoate (NaBA, A.C.S.), sodium chloride $(\mathrm{NaCl}$, A.C.S.), sodium phosphate dibasic $\left(\mathrm{Na}_{2} \mathrm{HPO}_{4}\right.$, A.C.S.), and sulfuric acid $\left(\mathrm{H}_{2} \mathrm{SO}_{4}\right.$, Optima $)$ were from Fisher Scientific. Sodium bisulfite $\left(\mathrm{NaHSO}_{3}\right.$, A.C.S.) was from GFS chemicals, and $p$-hydroxybenzoic acid ( $p$-HBA) was from TCI America. Purified water $(\geq 18.2 \mathrm{M} \Omega \mathrm{cm})$ was obtained from a Milli-Q Plus system (Millipore).

\subsection{Surrogate lung fluid (SLF)}

All experiments were performed in a cell-free SLF solution that contained $114 \mathrm{mM} \mathrm{NaCl}, 10.0 \mathrm{mM}$ total phosphate (7.8 $\mathrm{mM} \mathrm{Na}_{2} \mathrm{HPO}_{4}$ and $2.2 \mathrm{mM} \mathrm{KH}_{2} \mathrm{PO}_{4}$ ) to buffer the solution at $\mathrm{pH} 7.2$ to 7.4 , and $10 \mathrm{mMNaBA}$ as a chemical probe to detect ${ }^{\bullet} \mathrm{OH}$. Prior to particle extraction, transition metals were removed from the SLF using a column filled with chelex-100. The SLF was then refrigerated and generally used within one month of preparation. In most cases, right before the start of sample extraction, freshly made Asc was added to the SLF to get a final concentration of $50 \mu \mathrm{M}$, similar to endogenous concentrations of the reductant (Cross et al., 1994; van der Vliet et al., 1999).

\subsection{PM collection and extraction}

Fine $\left(\mathrm{PM}_{2.5}\right)$ and coarse $\left(\mathrm{PM}_{\mathrm{cf}}\right)$ particle samples were collected at an urban (Fresno) and rural (Westside) site in California's SJV during summer and winter between 2006 and 2009 by other researchers from UC Davis. A total of twelve samples were collected, with one $\mathrm{PM}_{2.5}$ sample and one $\mathrm{PM}_{\mathrm{cf}}$ sample taken during each sampling period. After collection samples were kept at $-20^{\circ} \mathrm{C}$ until analysis. Although our storage times were quite long (approximately 1 to $4 \mathrm{yr}$; Table S1), we do not believe that this significantly reduced the ability of the particles to produce ROS since metals were the dominant redox-active species on the particles (Sect. 3.3) and we added fresh Asc to the SLF on each experiment day. PM masses were determined using a Mettler Toledo XP26 microbalance with $1 \mu \mathrm{g}$ precision. Generally, for a given sample the $\mathrm{PM}_{2.5}$ mass concentration was greater than the corresponding $\mathrm{PM}_{\mathrm{cf}}$. Additional information about sample PM masses, and PM mass extraction efficiencies (69-97\%), are in our HOOH study (Shen et al., 2011).

For ${ }^{\bullet} \mathrm{OH}$ measurements, a punch of filter $\left(\mathrm{PM}_{2.5}\right.$ sample) or a piece of foil $\left(\mathrm{PM}_{\mathrm{cf}}\right.$ sample) was placed in a 7-ml 
perfluoroalkoxy (PFA) Teflon vial that was pre-washed with nitric acid to remove transition metals. After adding $6.0 \mathrm{ml}$ of SLF and, in most cases, Asc with the final concentration of $50 \mu \mathrm{M}$, the vials were completely wrapped with aluminum foil, placed on a wrist-action shake table (VWR OS-500, set at " 5 "), and shaken in the dark at room temperature for up to $24 \mathrm{~h}$. For a given sample, each PM extraction was performed on a different punch (or piece) of sample cut from the same filter (or foil) and thus the number of replicates $(n)$ in each figure represents multiple independent measurements of the same sample. For every experiment day we also "extracted" three different types of controls the same way as we treated the PM samples: (1) an SLF solution blank, (2) corresponding field blanks, i.e. filter or foil substrate that had been placed in the sampler in the field without collecting sample, and (3) $250 \mathrm{nM}$ of $\mathrm{CuSO}_{4}$ in SLF with Asc as a positive control. To examine the role of transition metals in ${ }^{\bullet} \mathrm{OH}$ formation, in some experiments the chelator DSF was added to the SLF (for a final concentration of $1.0 \mathrm{mM}$ ) before adding Asc.

\section{$2.4 \cdot O H$ determinations}

- $\mathrm{OH}$ in our experiments was determined using $10 \mathrm{mM}$ benzoate as a chemical probe (Anastasio and McGregor, 2001; Jung et al., 2006): as ${ }^{\bullet} \mathrm{OH}$ is generated in the extract solution, it reacts with benzoate to form $p$-HBA, a stable product that is quantified by HPLC. The HPLC consisted of a Shimadzu SIL-10AF autosampler with CMB-20A controller, a Shimadzu LC-10ATVP pump, a Keystone Scientific C-18 Beta Basic reverse-phase column $(3 \times 250 \mathrm{~mm}, 5 \mu \mathrm{m}$ bead $)$ with an attached guard column, and a Shimadzu SPD-10 AV UV-Visible detector $(\lambda=256 \mathrm{~nm})$. The eluent was $30 \%$ $\mathrm{CH}_{3} \mathrm{CN}$ and $70 \% \mathrm{H}_{2} \mathrm{O}$ adjusted to $\mathrm{pH} 2$ with $\mathrm{HClO}_{4}$, continuously degassed with a slow stream of helium (99.997\%), and run at a flow rate of $0.60 \mathrm{ml} \mathrm{min}-1$. A $500 \mu \mathrm{l}$ aliquot of PM extraction solution was analyzed for $p$-HBA after $0,1,2$, and $24 \mathrm{~h}$ of shaking. The extract was quickly filtered using a $0.22 \mu \mathrm{m}$ syringe filter (Milex Millipore) and transferred into an autosampler vial (Fisher Scientific), where it was mixed with $100 \mu \mathrm{M} \mathrm{DSF}$ and $50 \mu \mathrm{M} \mathrm{HSO}_{3}^{-}$to quench ${ }^{\bullet} \mathrm{OH}$ generation. After $10 \mathrm{~min}$ in the dark, the extract was acidified to $\mathrm{pH}$ 2 by adding $5 \mu \mathrm{l}$ of $1.0 \mathrm{M} \mathrm{H}_{2} \mathrm{SO}_{4}$. Samples were stored at 4 to $8^{\circ} \mathrm{C}$ until $\mathrm{HPLC}$ analysis.

The concentration of $p$-HBA in each sample was quantified using a calibration curve produced from $p$-HBA standards in SLF run on the same day of experiment. The ${ }^{\bullet} \mathrm{OH}$ concentration in each sample was calculated using (Jung et al., 2006):

$\left[{ }^{\bullet} \mathrm{OH}\right]=[p-\mathrm{HBA}] /\left(Y_{p-\mathrm{HBA}} \times f_{\mathrm{BA}}\right)$

where $[p-\mathrm{HBA}]$ is the measured concentration of $p$-HBA, $Y_{p-\mathrm{HBA}}$ is the molar yield of $p$-HBA from the reaction of -OH with BA in SLF $(0.215 \pm 0.018)$ (Jung et al., 2006), and $f_{\mathrm{BA}}$ is the fraction of ${ }^{\bullet} \mathrm{OH}$ that reacts with $\mathrm{BA}$ in a specific SLF. Based on published rate constants for ${ }^{\bullet} \mathrm{OH}$ (Walling et al., 1974; Buxton et al., 1988; Zepp et al., 1992) we calculated values of $f_{\mathrm{BA}}$ to be 0.9999 in the absence of Asc or DSF, 0.9972 with Asc, and 0.8175 with both Asc and DSF.

We used a similar procedure to determine rates of $\bullet \mathrm{OH}$ production from the data of DiStefano et al. (2009), who extracted particles at $37^{\circ} \mathrm{C}$ in a pH 6.4 phosphate solution containing $500 \mu \mathrm{M}$ salicylate anion (SA, aka 2hydroxybenzoate) as the chemical probe for ${ }^{\bullet} \mathrm{OH}$ and $500 \mu \mathrm{M}$ ascorbate. They reported the sum $\left(R_{2,3}\right.$-DHBA +

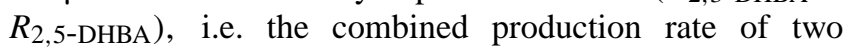
of the products from the $\cdot \mathrm{OH}+\mathrm{SA}$ reaction, 2,3dihydroxybenzoate (2,3-DHBA) and 2,5-dihydroxybenzoate (2,5-DHBA). We calculated rates of ${ }^{\bullet} \mathrm{OH}$ formation $(R \cdot \mathrm{OH})$ from their data using an equation analogous to Eq. (1):

$$
\begin{aligned}
& R \cdot \mathrm{OH}=\left(R_{2,3}-\mathrm{DHBA}+R_{2,5}-\mathrm{DHBA}\right) / \\
& \quad\left(\left(Y_{2,3}-\mathrm{DHBA}+Y_{2,5}-\mathrm{DHBA}\right) \times f_{\mathrm{SA}}\right)
\end{aligned}
$$

where $\left(Y_{2,3-\mathrm{DHBA}}+Y_{2,5-\mathrm{DHBA}}\right)$ is the sum of the molar yields of 2,3-DHBA and 2,5-DHBA from the ${ }^{\bullet} \mathrm{OH}+\mathrm{SA}$ reaction, and $f_{\mathrm{SA}}$ is the fraction of ${ }^{\bullet} \mathrm{OH}$ that reacts with SA in their PM extraction solution. From data of Bektasoglu and co-workers $\left(37^{\circ} \mathrm{C}, \mathrm{pH} 7.0\right)$, we calculate the value of $\left(Y_{2,3 \text {-DHBA }}+Y_{2,5 \text {-DHBA }}\right)$ to be 0.60 (Bektasoglu et al., 2008). Based on the NIST compilation (Buxton et al., 1988), the average room temperature rate constants for ${ }^{\bullet} \mathrm{OH}$ with SA and Asc are $1.6 \times 10^{10} \mathrm{M}^{-1} \mathrm{~s}^{-1}$ and $6.4 \times 10^{9} \mathrm{M}^{-1} \mathrm{~s}^{-1}$, respectively, while the phosphate buffer is a negligible ${ }^{\bullet} \mathrm{OH}$ sink. Thus, by following the procedure of Charrier and Anastasio (Charrier and Anastasio, 2011), we calculate that $f_{\mathrm{SA}}=0.71$ in the experiments of DiStefano et al. (2009).

\subsection{ICP-MS analysis of transition metals}

$400 \mu \mathrm{l}$ of filtered 24-h PM extract was diluted with $3.6 \mathrm{ml}$ of $3 \% \mathrm{HNO}_{3}$ into an acid-rinsed 15 -ml Corning® polypropylene centrifuge tube, and refrigerated until analysis. Samples were analyzed for $\mathrm{Cu}, \mathrm{Fe}, \mathrm{V}$, and $\mathrm{Mn}$ using an Agilent 7500CE ICP-MS. A series of metal standards was prepared for quality control purposes (Shen et al., 2011). Metal concentrations for each PM sample extract were corrected for the metal amount in the corresponding field blank.

\subsection{Data analysis}

Two parameters were determined for each PM extract: (1) the initial rate of ${ }^{\bullet} \mathrm{OH}$ formation, calculated using the 0 and $1 \mathrm{~h}$ time points, and (2) the maximum ${ }^{\circ} \mathrm{OH}$ formed after $24 \mathrm{~h}$ of extraction (i.e. the total amount of ${ }^{\bullet} \mathrm{OH}$ formed during the $24 \mathrm{~h}$ ). Our initial rate of ${ }^{\bullet} \mathrm{OH}$ formation likely underestimates the true value since we used $1 \mathrm{~h}$ instead of an earlier time point for the rate calculation. Likewise, since samples typically formed ${ }^{\bullet} \mathrm{OH}$ throughout the extraction, the $24-\mathrm{h}{ }^{\bullet} \mathrm{OH}$ value will often underestimate the true maximum.

The rate of $\bullet \mathrm{OH}$ formation in each PM extract was blankcorrected, positive-control-normalized, and expressed relative to the sampled air volume using 
Corrected Rate of $\bullet \mathrm{OH}\left(\mathrm{nmol} \mathrm{h}^{-1} \mathrm{~m}^{-3}\right)$

Sample Rate - Field Blank Rate

$=\overline{\text { Daily Positive Control Rate }- \text { Daily SLF Blank Rate }}$

$\times$ Average Positive Control Rate $\times 1000 \mathrm{nmol}^{\mu \mathrm{mol}^{-1} \times \text { ExtractVolume }^{-}}$ Air Volume Sampled

where all rates are in $\mu \mathrm{Mh}^{-1}$. The average positive control rate was $0.381 \pm 0.061 \mu \mathrm{Mh}^{-1}$. Each extract volume was 0.00601 , while the air volumes sampled for each $\mathrm{PM}_{2.5}$ and $\mathrm{PM}_{\mathrm{cf}}$ sample piece were 2.346 and $21.444 \mathrm{~m}^{3}$, respectively. Analogous equations were used to calculate the airvolume-normalized maximum ${ }^{\bullet} \mathrm{OH}$ formation (average positive control maximum $=2.83 \pm 0.24 \mu \mathrm{M}$ ) and the PM-massnormalized ${ }^{\bullet} \mathrm{OH}$ rates and maxima. We normalized sample results to the positive control because we found that ${ }^{\bullet} \mathrm{OH}$ generation from the positive control was covariant with sample and blank values on the same day of experiment; the positive control varied within a range of approximately $-30 \%$ to $+27 \%$ relative to its average value.

Data were analyzed using SPSS 12.0 (SPSS) and SigmaPlot 11.0 (Systat Software) and presented as means \pm SD or medians and upper and lower quartiles and extremes using box and whisker plots. Comparisons of $\bullet$ OH generation among different PM samples were performed using oneway ANOVA followed by Bonferroni post hoc test. Differences in means were considered significant when $P<0.05$.

\section{Results and discussion}

Figure 2 shows some examples of the time course of $\bullet \mathrm{OH}$ generation from SJV PM, and the $\mathrm{Cu}$ (II) positive control, during our 24-h extraction. As shown in this figure, the solution blanks and field blanks generated very low levels of $\bullet \mathrm{OH}$. In contrast, ${ }^{\bullet} \mathrm{OH}$ production from the positive control reached a concentration of approximately $1.7 \mu \mathrm{M}$ at $4 \mathrm{~h}$ and continued to rise, though more slowly, at longer times. As also illustrated in the figure, and described in more detail below, Fresno PM was more active in forming ${ }^{\bullet} \mathrm{OH}$ than Westside PM. As described in Sect. 2.6, we used the 0 and $1 \mathrm{~h}$ time points to estimate the initial rate of $\bullet \mathrm{OH}$ formation and reported the 24-h time point value as the "maximum" amount of ${ }^{\bullet} \mathrm{OH}$ formed (i.e. the total ${ }^{\bullet} \mathrm{OH}$ formed over $24 \mathrm{~h}$ ), although more ${ }^{\bullet} \mathrm{OH}$ is likely to be formed after this point in at least some of the samples.

We normalized the initial rate of ${ }^{\bullet} \mathrm{OH}$ formation, and maximum ${ }^{\bullet} \mathrm{OH}$ concentration, in each PM extract in two different ways: (1) to the air volume sampled during PM collection (e.g. nmol- ${ }^{\bullet} \mathrm{OH} \mathrm{h} \mathrm{h}^{-1} \mathrm{~m}^{-3}$-air) and (2) to the extracted PM mass (e.g. nmol- ${ }^{\bullet} \mathrm{OH} \mathrm{h}^{-1} \mathrm{mg}^{-1}$-PM). The two ways of normalization are relevant to PM inhalation studies and PM instillation studies, respectively (Shen et al., 2011).

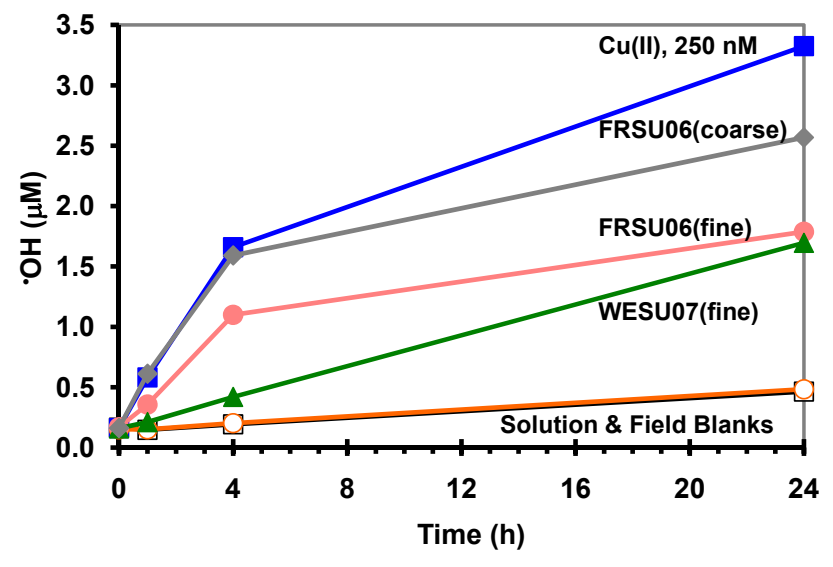

Fig. 2. Examples of $\bullet \mathrm{OH}$ generation from fine and coarse San Joaquin Valley particles extracted in a surrogate lung fluid containing $50 \mu \mathrm{M}$ ascorbate. Sample nomenclature: FRSU06 $=$ Fresno summer 2006, WESU07 = Westside summer 2007, $250 \mathrm{nM} \mathrm{Cu}$ (II) $=$ positive control.

\subsection{Generation of ${ }^{\bullet} \mathrm{OH}$ in $\mathrm{PM}$ extracts with added ascorbate}

We first quantified ${ }^{\bullet} \mathrm{OH}$ generation from SJV PM extracted in SLF with $50 \mu \mathrm{M}$ of added ascorbate, an important antioxidant in human lung lining fluid (Cross et al., 1994; van der Vliet et al., 1999). As shown in Fig. 1, ascorbate can also act as a pro-oxidant by recycling transition metals from oxidized to reduced forms, thus promoting ROS generation (Stadtman, 1991; Satoh and Sakagami, 1997; McGregor and Biesalski, 2006; Vidrio et al., 2008; Shen et al., 2011).

In the presence of ascorbate, the Fresno (urban) particles are generally much more reactive than the Westside (rural) particles in generating $\bullet \mathrm{OH}$, on both an air-volume and PMmass normalized basis. The initial rates of $\bullet$ OH formation are shown in Fig. $3 a$ and b: on average, the Fresno fine and coarse particles are 5.5 and 11.4 times more reactive, respectively, than their Westside counterparts for air-volume normalized rates (and 4.1 and 16.1 times more effective, respectively, for PM-mass normalized rates). Based on the airvolume-normalization, the fine particles are generally more important sources of ${ }^{\bullet} \mathrm{OH}$ than the coarse particles in the ambient aerosol (Fig. 3a); as we described earlier for $\mathrm{HOOH}$, this is because the $\mathrm{PM}_{2.5}$ mass concentration is much higher than the $\mathrm{PM}_{\mathrm{cf}}$ mass concentration during each sampling period (Shen et al., 2011). On the other hand, on a PM-massnormalized basis, the coarse particles are typically somewhat more efficient than the fine particles at generating $\bullet \mathrm{OH}$ (Fig. 3b). We see the same relative importance of fine particles (dominating air-volume-normalized $\bullet \mathrm{OH}$ generation) and coarse particles (more efficient on a mass-normalized basis) for the maximum ${ }^{\bullet} \mathrm{OH}$ measured (Fig. S1). Although our sample size is small, we find no apparent seasonal difference in either the initial rate of ${ }^{\bullet} \mathrm{OH}$ generation (Fig. 3) or in 
a

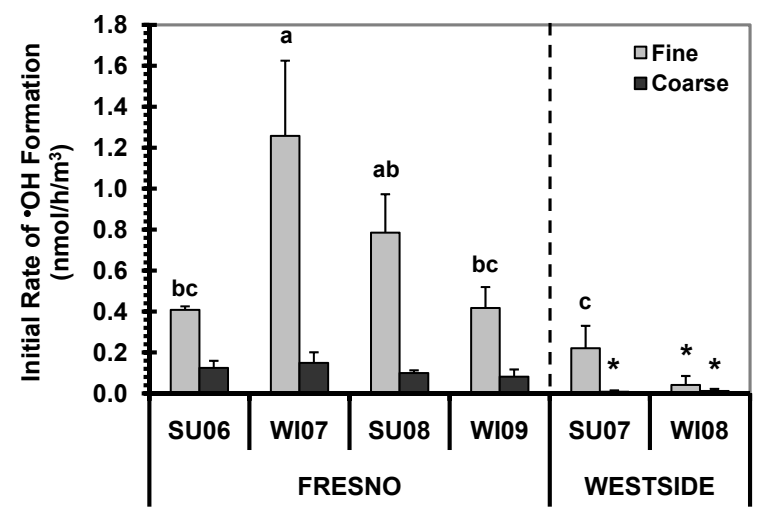

b

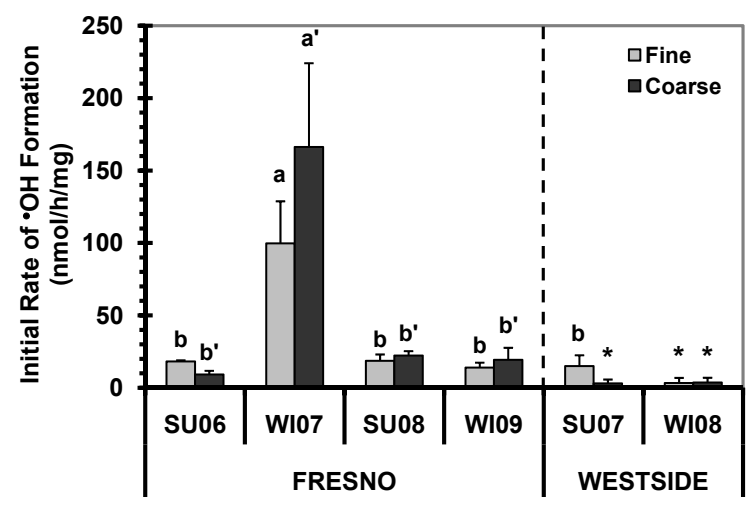

Fig. 3. Rates of $\bullet \mathrm{OH}$ generation in the presence of $50 \mu \mathrm{M}$ ascorbate. Panel (a) shows air-volume-normalized initial rates of $\bullet{ }^{\bullet} \mathrm{OH}$ formation, while (b) shows PM-mass-normalized initial rates. Sample nomenclature: $\mathrm{SU}=$ summer, $\mathrm{WI}=$ winter, and " $0 \mathrm{x}$ " represents the year of sample collection (200x). ${ }^{\bullet} \mathrm{OH}$ values are means $\pm \mathrm{SD}$, $n=3$ to 4 . Letters above bars indicate statistically different rates: $a>b>c$ for fine PM, while $a^{\prime}>b^{\prime}$ for coarse PM. An asterisk “*”, indicates the value is not statistically different from zero. The airvolume-normalized initial rates of ${ }^{\bullet} \mathrm{OH}$ formation from the Fresno coarse PM are not statistically different from each other.

the maximum ${ }^{\bullet} \mathrm{OH}$ formation (Fig. S1). The results of ${ }^{\bullet} \mathrm{OH}$ generation in SLF with added Asc are consistent with our previous findings of $\mathrm{HOOH}$ formation in the same SLF: (1) the urban samples generate more $\mathrm{HOOH}$ than the rural samples, (2) fine PM generally makes more $\mathrm{HOOH}$ than coarse PM per volume of air, (3) coarse PM typically produces more $\mathrm{HOOH}$ than fine PM per mass unit of PM, and (4) there is no seasonal difference in $\mathrm{HOOH}$ generation (Shen et al., 2011).

Figure $4 \mathrm{a}$ and $\mathrm{b}$ compare the maximum ${ }^{\bullet} \mathrm{OH}$ generation from our Fresno and Westside $\mathrm{PM}$ with ${ }^{\bullet} \mathrm{OH}$ formation from Davis $\mathrm{PM}_{2.5}$ (Vidrio et al., 2009) . While the surrogate lung fluid we used here contained $50 \mu \mathrm{M}$ Asc, the Davis particles were extracted in a fluid containing $200 \mu \mathrm{M}$ Asc and $300 \mu \mathrm{M}$

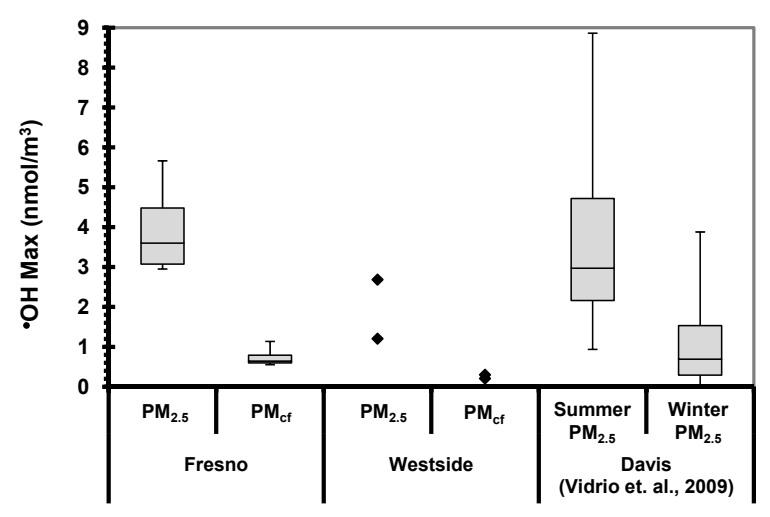

b
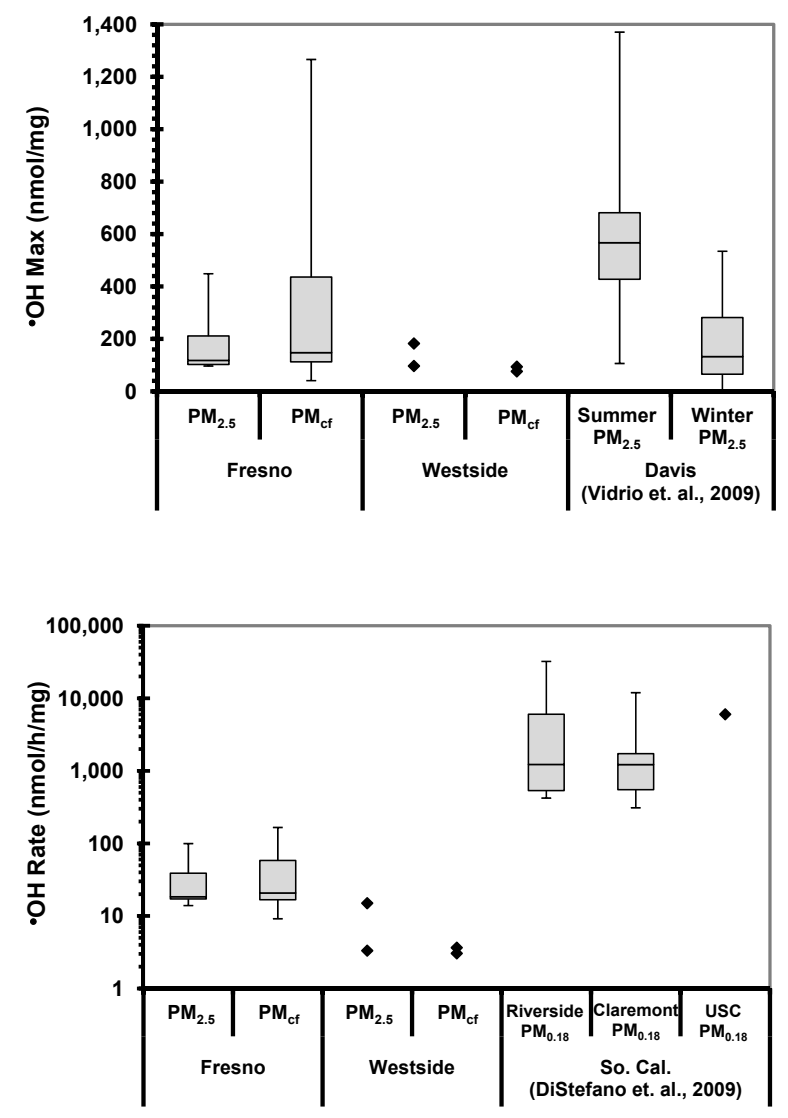

Fig. 4. Comparison of ${ }^{\bullet} \mathrm{OH}$ generation in SJV PM with results for $\mathrm{PM}_{2.5}$ from Davis, California (Vidrio et al., 2009), shown in (a) and (b), and $\mathrm{PM}_{0.18}$ from southern California (DiStefano et al., 2009), shown in (c). The Davis PM were extracted for $24 \mathrm{~h}$ at room temperature in a similar surrogate lung fluid, but with $200 \mu \mathrm{M}$ ascorbate and $300 \mu \mathrm{M}$ citrate (Vidrio et al., 2009). The southern California PM were extracted for $45 \mathrm{~min}$ at $37^{\circ} \mathrm{C}$ in a pH 6.4 solution containing $500 \mu \mathrm{M}$ ascorbate and $500 \mu \mathrm{M}$ salicylate as the ${ }^{\bullet} \mathrm{OH}$ probe (DiStefano et al., 2009). Each box and whisker plot shows the median, upper and lower quartiles, and upper and lower extremes. 
citrate (Cit), conditions that reduce the effectiveness of $\mathrm{Cu}$ at generating ${ }^{\bullet} \mathrm{OH}$ but increase the effectiveness of $\mathrm{Fe}$ (Charrier and Anastasio, 2011). Despite the differences in SLF composition, the maximum amount of ${ }^{\bullet} \mathrm{OH}$ generated by our Fresno $\mathrm{PM}_{2.5}$ is comparable to the Davis $\mathrm{PM}_{2.5}$ results (Fig. 4), although the Davis samples show a clear seasonal difference in - $\mathrm{OH}$ generation, with the spring/summer $\mathrm{PM}_{2.5}$ much more efficient in producing ${ }^{\bullet} \mathrm{OH}$ than the winter $\mathrm{PM}_{2.5}$ (Vidrio et al., 2009).

We can also compare our initial rates of $\bullet \mathrm{OH}_{\text {generation }}$ in Fresno and Westside PM extracts with values determined from southern California quasi-ultrafine $\mathrm{PM}\left(\mathrm{PM}_{0.18}\right)$, which were extracted in a pH 6.4 solution containing $500 \mu \mathrm{M}$ Asc (DiStefano et al., 2009). The PM-mass-normalized initial rates of ${ }^{\bullet} \mathrm{OH}$ generation for our Fresno (and Westside) PM are much lower than the ${ }^{\bullet} \mathrm{OH}$ rates for the southern California $\mathrm{PM}_{0.18}$ (Fig. 4c), with median values of $18,21,1225$, and $1218 \mathrm{nmol} \mathrm{h}^{-1} \mathrm{mg}^{-1}$ for the Fresno $\mathrm{PM}_{2.5}$, Fresno $\mathrm{PM}_{\mathrm{cf}}$, Riverside $\mathrm{PM}_{0.18}$, and Claremont $\mathrm{PM}_{0.18}$, respectively. Thus, the southern California $\mathrm{PM}_{0.18}$ are approximately 60 times more reactive than the Fresno fine and coarse PM in generating ${ }^{\bullet} \mathrm{OH}$. However, the extraction conditions in these two studies were quite different: the southern California $\mathrm{PM}_{0.18}$ were extracted at a much higher temperature $\left(37^{\circ} \mathrm{C}\right.$, compared to room temperature in our experiments) and with a 10fold higher concentration of ascorbate $(500 \mu \mathrm{M}$, compared with $50 \mu \mathrm{M}$ in our experiments). These methodological differences can probably account for much of the difference in - $\mathrm{OH}$ rates seen between our Fresno PM and the southern California $\mathrm{PM}_{0.18}$ : (1) based on results in a more complicated surrogate lung fluid $(200 \mu \mathrm{M}$ Asc, $300 \mu \mathrm{M}$ Cit, $100 \mu \mathrm{M}$ glutathione, and $100 \mu \mathrm{M}$ uric acid), we find that the rate of ${ }^{\circ} \mathrm{OH}$ production from dissolved $\mathrm{Fe}$ is approximately 5 times faster at $37^{\circ} \mathrm{C}$ compared to room temperature (J. Charrier, personal communication, 2011), (2) the rate of ${ }^{\bullet} \mathrm{OH}$ generation in a $500 \mu \mathrm{M}$ Asc solution is likely close to 10-times faster than in a $50 \mu \mathrm{M}$ Asc solution, and (3) if these effects are multiplicative, the southern California $\mathrm{PM}_{0.18}$ rates of ${ }^{\bullet} \mathrm{OH}$ production should be approximately 50 times faster than the Fresno PM solely because of extraction differences, which is close to the observed factor of 60 (Fig. 4c). Thus, while the southern California $\mathrm{PM}_{0.18}$ particles are likely somewhat more reactive than the Fresno $\mathrm{PM}_{2.5}$ and $\mathrm{PM}_{\mathrm{cf}}$, the difference is probably greatly magnified in Fig. $4 \mathrm{c}$ because of the variation in extraction conditions.

\subsection{Generation of ${ }^{\bullet} \mathrm{OH}$ in $\mathrm{PM}$ extracts without added ascorbate}

- $\mathrm{OH}$ production in the SJV PM extracts above were all in SLF containing $50 \mu \mathrm{M}$ ascorbate, which mimics the lung lining fluid concentration (Cross et al., 1994; van der Vliet et al., 1999). To examine the importance of ascorbate on ${ }^{\bullet} \mathrm{OH}$ generation, we also measured ${ }^{\bullet} \mathrm{OH}$ formation in PM extracts without added Asc. As shown in Fig. 5, there was essen- tially no ${ }^{\bullet} \mathrm{OH}$ generation in the fine and coarse PM extracts within the first $1 \mathrm{~h}$ in the absence of Asc, with one exception - Fresno Winter $2009 \mathrm{PM}_{2.5}$. In this sample the initial rate of ${ }^{\bullet} \mathrm{OH}$ formation in SLF without Asc (Fig. 5) was 11 times lower than the rate measured in SLF with added Asc (Fig. 3). However, given that this sample had the highest rate of ${ }^{\bullet} \mathrm{OH}$ formation in the absence of ascorbate, it might be underestimating the typical impact of Asc on ${ }^{\bullet} \mathrm{OH}$ generation. Indeed, as shown in Fig. 6, in this sample the presence of ascorbate had the weakest amplifying effect on the rate of $\bullet \mathrm{OH}$ generation (a factor of 11), compared to factors ranging from 21 to 4500 in the other samples (with an overall median value of approximately 50), independent of whether ${ }^{\circ} \mathrm{OH}$ results are normalized to air volume or PM mass. These results are consistent with our previous results on $\mathrm{HOOH}$ generation by SJV PM, where the presence of ascorbate also greatly amplified $\mathrm{HOOH}$ formation, with a median enhancement of a factor of 19 (Shen et al., 2011).

As with the initial rate of ${ }^{\circ} \mathrm{OH}$ formation, the maximum amounts of ${ }^{\bullet} \mathrm{OH}$ formed in SLF without added Asc (Fig. S2) were also much lower than those in SLF with added Asc (Fig. S1). The presence of ascorbate amplified the maximum ${ }^{\bullet} \mathrm{OH}$ formation from the SJV PM by factors of 6 to 258 (Fig. S3), with a median value of approximately 60 . In the absence of Asc, the Fresno winter 2007 coarse PM generated the highest ${ }^{\bullet} \mathrm{OH}$ maximum, followed by the Fresno summer 2008 and winter 2009 coarse PM (Fig. S2). The relatively high production of ${ }^{\bullet} \mathrm{OH}$ by the Fresno winter 2007 coarse $\mathrm{PM}$ is especially pronounced on a PM mass-normalized basis (Fig. S2b), and could be due to the role of redox-active organic compounds such as quinones (Dellinger et al., 2001; Rodriguez et al., 2005; Valavanidis et al., 2008). The generation of ${ }^{\bullet} \mathrm{OH}$ in the absence of ascorbate by several samples suggests these particles contain unidentified reductants that can reduce oxidized forms of metals and/or organics to form - OH (Fig. S2). However, while ${ }^{\bullet} \mathrm{OH}$ generation in the absence of ascorbate in these few samples is interesting, as we describe below, ${ }^{\bullet} \mathrm{OH}$ generation in our PM samples is dominated by soluble transition metals utilizing ascorbate as the reductant.

We can use our results with and without ascorbate to discern the relative importance of the different acellular mechanisms by which particles can produce ${ }^{\bullet} \mathrm{OH}$ and $\mathrm{HOOH}$ during aqueous extraction. There are at least three of these mechanisms: (1) dissolution of particle-bound ROS such as peroxides (HOOH, ROOH, ROOR') into solution, (2) reactions of particle-bound ROS precursors, e.g. reduced forms of redox-active species such as $\mathrm{Fe}(\mathrm{II})$, to make ROS in solution, and (3) redox-cycling reactions where particle components (e.g. $\mathrm{Cu}$ ) interact with reductants in the extraction solution (e.g. ascorbate) to form ROS. Comparing the amount of ROS formed in the presence of Asc (where all three mechanisms contribute) to the amount formed in the absence of Asc (where only mechanisms (1) and (2) contribute) indicates the relative importance of these mechanisms. For our Fresno 


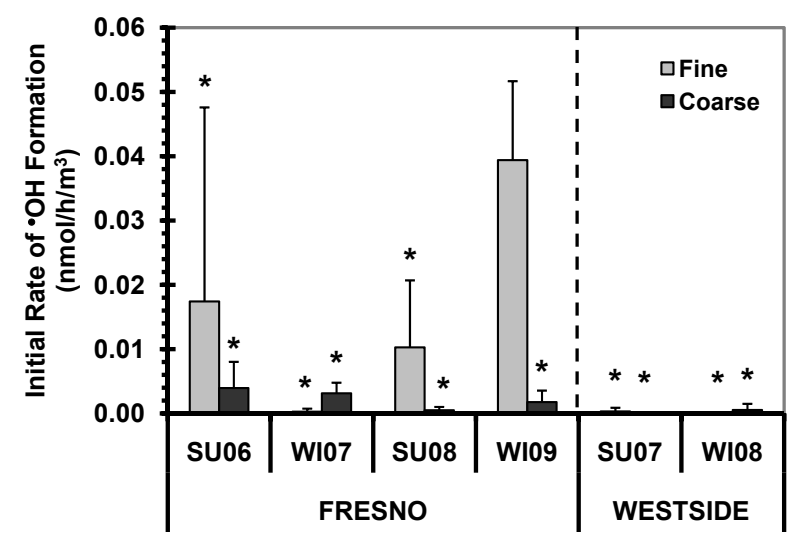

b

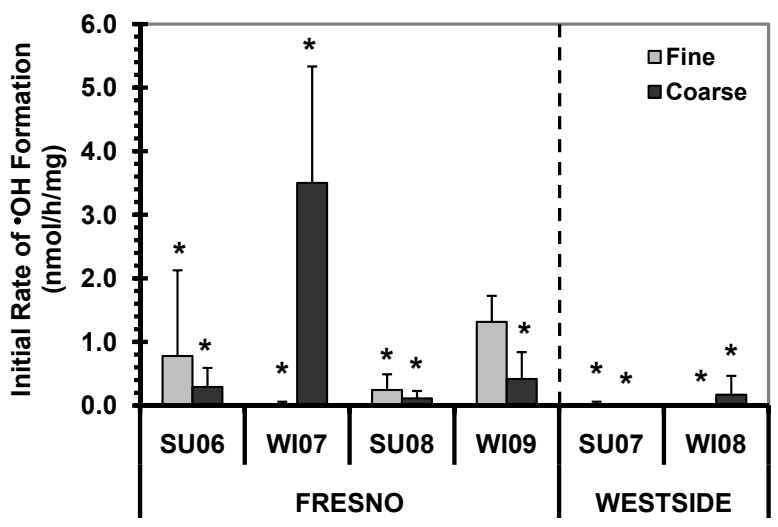

Fig. 5. Rates of ${ }^{\bullet} \mathrm{OH}$ generation in the absence of ascorbate. Panel (a) shows air-volume-normalized initial rates of $\bullet$ OH formation, while (b) shows PM-mass-normalized initial rates. Values are means $\pm \mathrm{SD}, n=3$. An asterisk "*" indicates a value that is not statistically different from zero.

samples, the median ratio of the ${ }^{\bullet} \mathrm{OH}$ formation rate in the presence of Asc to the ${ }^{\circ} \mathrm{OH}$ formation rate in the absence of Asc is 47 (Fig. 6). The same picture holds for $\mathrm{HOOH}$, where the analogous median ratio is 42 (Shen et al., 2011). These ratios strongly suggest that redox reactions involving endogenous reductants (mechanism (3)) are the dominant chemical sources of ROS from particles deposited in the lungs.

\subsection{SLF-soluble transition metals, especially $\mathrm{Cu}$, play a dominant role in ${ }^{\bullet} \mathrm{OH}$ generation from SJV PM}

As an initial step to explore the mechanisms of $\bullet$ OH generation from particles extracted in the presence of ascorbate, we performed parallel extractions in the presence of DSF, a strong metal chelator, in order to remove ${ }^{\circ} \mathrm{OH}$ generation by transition metals. As shown in Fig. 7, DSF is exceptionally

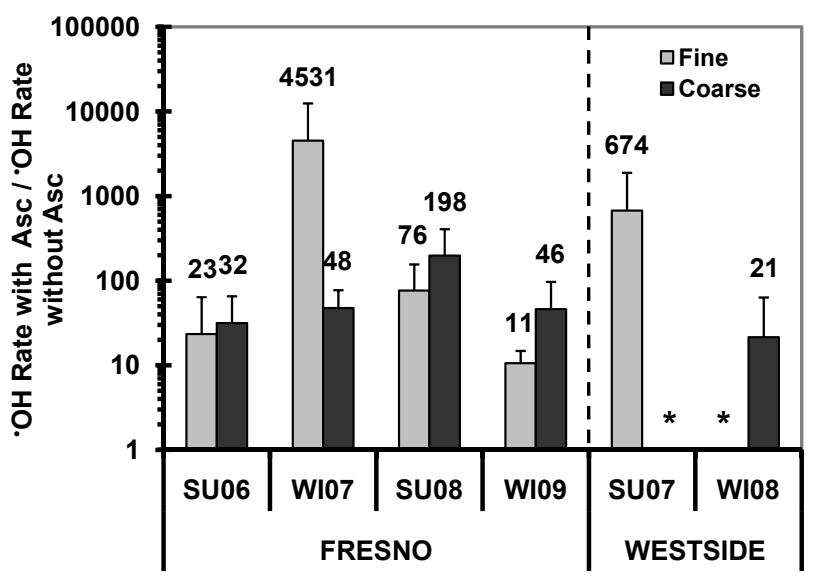

Fig. 6. Ratios of the initial rate of ${ }^{\bullet} \mathrm{OH}$ formation in SLF with ascorbate over the initial rate of ${ }^{\bullet} \mathrm{OH}$ formation in SLF without ascorbate. An asterisk “*” indicates that there is no ${ }^{\bullet} \mathrm{OH}$ generation within the first $1 \mathrm{~h}$ of extraction in SLF without Asc. Since the initial rate of ${ }^{\bullet} \mathrm{OH}$ formation without ascorbate in all samples except the Fresno winter 2009 fine PM was not statistically different from zero (Fig. 5), we are likely underestimating the effect of ascorbate in amplifying $\bullet \mathrm{OH}$ generation for most of the PM samples.

effective at reducing $\bullet \mathrm{OH}$ generation in extracts of PM from both sites: on average, adding DSF reduces the initial rate of ${ }^{\bullet} \mathrm{OH}$ formation by $94( \pm 8) \%$ for the fine PM and by 100 $( \pm 0.5) \%$ for the coarse PM. Similarly, DSF decreases the maximum ${ }^{\bullet} \mathrm{OH}$ formation by $98( \pm 2) \%$ and $98 \%( \pm 1) \%$ for the fine and coarse PM, respectively (Fig. S4). These results indicate that essentially all ${ }^{\bullet} \mathrm{OH}$ generation in the $\mathrm{PM}_{2.5}$ and $\mathrm{PM}_{\mathrm{cf}}$ extracts involved transition metals. As we reported previously, transition metals also dominated $\mathrm{HOOH}$ generation from these particles, although to a lesser extent compared to - $\mathrm{OH}$ : DSF reduced the initial rate of $\mathrm{HOOH}$ formation by 83 $( \pm 16) \%$ and $73( \pm 13) \%$, and the maximum $\mathrm{HOOH}$ formation by $78( \pm 12) \%$ and $63( \pm 14) \%$, for the fine and coarse particles, respectively (Shen et al., 2011).

As our second step in understanding the mechanisms for ${ }^{\bullet} \mathrm{OH}$ formation in the San Joaquin Valley particles, we specifically examined the contributions of SLF-soluble $\mathrm{Cu}$ and $\mathrm{Fe}$. We chose to focus on these metals since our $\mathrm{Cu}$ positive control is very effective in generating ${ }^{\bullet} \mathrm{OH}$ (e.g. Fig. 2) and previous studies have shown that both $\mathrm{Cu}$ and $\mathrm{Fe}$ can be effective sources of ROS (Vidrio et al., 2008, 2009; DiStefano et al., 2009; Rushton et al., 2010; Wang et al., 2010; Nawrot et al., 2009). A regression analysis shows that the air-volume-normalized initial rate of $\bullet \mathrm{OH}$ formation by Fresno fine and coarse PM is strongly linearly correlated with SLF-soluble $\mathrm{Cu}\left(R^{2}=0.98\right)$ (Fig. 8), suggesting that $\mathrm{Cu}$ plays a major role in ${ }^{\bullet} \mathrm{OH}$ formation in the Fresno particles. We also find a strong, but non-linear, relationship between the maximum amount of ${ }^{\bullet} \mathrm{OH}$ formed (normalized by air volume sampled) and SLF-soluble $\mathrm{Cu}$ in the Fresno 


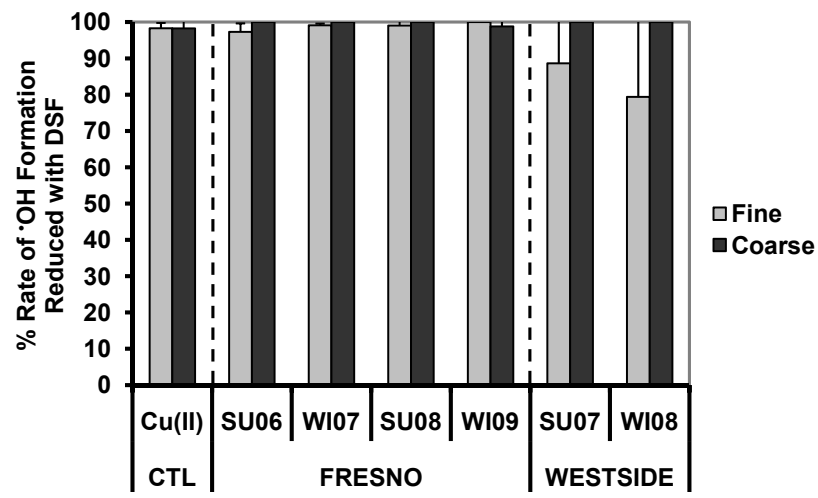

Fig. 7. Inhibitory effect of the transition metal chelator DSF on the initial rate of ${ }^{\bullet} \mathrm{OH}$ generation in SLF with ascorbate for the positive control and the SJV PM. Values are means \pm SD. $n=4$ for extractions without added DSF, and $n=2$ to 3 for extractions with added DSF

PM samples (Fig. S5). For the rural Westside particles there is no correlation between the initial rate of ${ }^{\circ} \mathrm{OH}$ formation (or maximum amount of ${ }^{\bullet} \mathrm{OH}$ formed) and SLF-soluble $\mathrm{Cu}$ (Fig. 8 and Fig. S5), but this is a very small sample set. In contrast to the strong correlations with $\mathrm{Cu}$ seen for the Fresno particles, SLF-soluble $\mathrm{Fe}$ is not correlated with the initial rate of ${ }^{\bullet} \mathrm{OH}$ formation $\left(R^{2}=0.05\right)$ or the maximum - OH concentration $\left(R^{2}=0.20\right)$. Similarly, we find no correlation between ${ }^{\bullet} \mathrm{OH}$ formation by the Fresno particles and either SLF-soluble V $\left(R^{2}=0.08\right.$ and 0.24 for initial rate and maximum $\left.{ }^{\bullet} \mathrm{OH}\right)$ or $\mathrm{Mn}\left(R^{2}=0.13\right.$ and 0.19 for initial rate and maximum $\bullet \mathrm{OH}$ ).

Our results are consistent with previous papers that have examined relationships between ${ }^{\bullet} \mathrm{OH}$ generation and soluble transition metals in ambient particle extracts. For example, Cho and co-workers (Distefano et al., 2009) also found that soluble $\mathrm{Cu}$ is strongly correlated with the rate of ${ }^{\bullet} \mathrm{OH}$ generation for $\mathrm{PM}_{0.18}$ from southern California, while there were no correlations between ${ }^{\bullet} \mathrm{OH}$ generation and soluble $\mathrm{Fe}, \mathrm{V}$, or $\mathrm{Mn}$. In contrast, for $\mathrm{PM}_{2.5}$ from Davis, CA, Vidrio et al. (2009) found no correlation between soluble $\mathrm{Fe}$ or $\mathrm{Cu}$ and the amount of ${ }^{\bullet} \mathrm{OH}$ formed by PM extracted for $24 \mathrm{~h}$ in SLF containing $200 \mu \mathrm{M}$ ascorbate and $300 \mu \mathrm{M}$ citrate. Despite the lack of correlation, a more mechanistic examination - involving quantifying ${ }^{\bullet} \mathrm{OH}$ generation from dissolved $\mathrm{Fe}$ and $\mathrm{Cu}$ in the SLF extracts of PM - revealed that soluble Fe could account for the bulk of ${ }^{\bullet} \mathrm{OH}$ generation from Davis PM (Vidrio et al., 2009).

In order to quantitatively understand the contributions of $\mathrm{Cu}$ and $\mathrm{Fe}$ towards ${ }^{\circ} \mathrm{OH}$ generation in our SJV particles, we also applied the technique of Vidrio et al. (2009) to our samples. This determination involves four steps: (1) making "calibration curves" that quantify the initial rate (and maximum concentration) of ${ }^{\bullet} \mathrm{OH}$ generated from known concentrations of dissolved $\mathrm{Cu}$ and $\mathrm{Fe}$ in SLF containing $50 \mu \mathrm{M}$

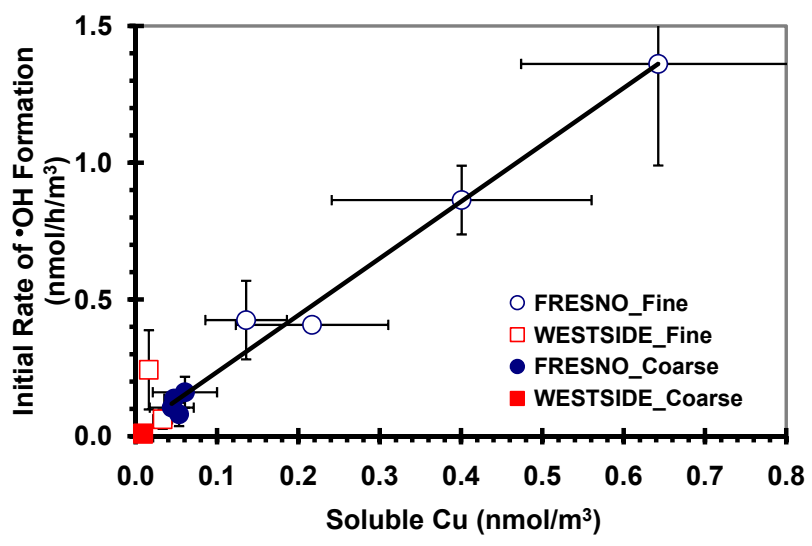

Fig. 8. Correlation between the air-volume-normalized initial rate of ${ }^{\bullet} \mathrm{OH}$ generation in SLF with Asc and the accompanying SLFsoluble $\mathrm{Cu}$ concentration. Values are means $\pm \mathrm{SD}$. $n=6$ except for a few of the $\mathrm{Cu}$ concentrations where $n=4$. The initial rates of - OH formation by Fresno fine and coarse PM were strongly correlated with the SLF-soluble $\mathrm{Cu}$ concentrations in corresponding PM extracts: $y=2.08 x+0.03, R^{2}=0.98$. No correlation was observed between the SLF-soluble $\mathrm{Cu}$ concentrations and the initial rates of - OH formation from the Westside PM $\left(R^{2}=0.03\right)$.

ascorbate (Shen and Anastasio, 2011); (2) measuring the concentrations of dissolved $\mathrm{Cu}$ and $\mathrm{Fe}$ in each of the 24-h PM extracts; (3) calculating the initial rate (and maximum concentration) of ${ }^{\bullet} \mathrm{OH}$ expected for each $\mathrm{PM}$ extract based on the measured $\mathrm{Cu}$ or $\mathrm{Fe}$ in the extract and our "calibration curves", and (4) calculating the ratio of the calculated ${ }^{\bullet} \mathrm{OH}$ rate (or maximum) from $\mathrm{Cu}$ or $\mathrm{Fe}$ to the measured ${ }^{\bullet} \mathrm{OH}$ rate (or maximum) in a given sample. This ratio (i.e. calculated - $\mathrm{OH}$ from $\mathrm{Cu}$ (or $\mathrm{Fe}$ )/measured ${ }^{\bullet} \mathrm{OH}$ in extract) is equivalent to the fraction of the observed ${ }^{\bullet} \mathrm{OH}$ that can be attributed to reactions of copper (or iron).

As shown in Fig. 9, $\mathrm{Cu}$ dominates ${ }^{\bullet} \mathrm{OH}$ formation in the Fresno PM samples. On average, $\mathrm{Cu}$ accounts for $89 \pm 18 \%$ of the initial rate of ${ }^{\bullet} \mathrm{OH}$ generation in the Fresno $\mathrm{PM}_{2.5}$ extracts and $89 \pm 23 \%$ in the Fresno $\mathrm{PM}_{\mathrm{cf}}$ extracts. Similarly, $\mathrm{Cu}$ can account for $156 \pm 23 \%$ and $107 \pm 27 \%$ of the maximum ${ }^{\bullet} \mathrm{OH}$ generated in the Fresno fine and coarse PM extracts, respectively (Fig. S6). While Fe also contributed to - OH generation, it played a smaller role, accounting for less than $30 \%$ of the ${ }^{\circ} \mathrm{OH}$ rate or maximum in the Fresno fine and coarse PM extracts (Figs. 9 and S6). For the Westside PM samples the picture is less clear, in part because the ${ }^{\bullet} \mathrm{OH}$ production was generally much smaller and thus less certain, but $\mathrm{Cu}$ was also the dominant source of ${ }^{\bullet} \mathrm{OH}$ in these samples (Figs. 9 and S6).

Together, SLF-soluble $\mathrm{Cu}$ and $\mathrm{Fe}$ can account for all of the ${ }^{\bullet} \mathrm{OH}$ formed in our PM extracts (Figs. 9 and S6). For the Fresno samples the average sum of ratios for the Fresno fine and coarse PM are $1.07 \pm 0.41$ and $0.96 \pm 0.49$ for the rate of ${ }^{\bullet} \mathrm{OH}$ formation, and $1.84 \pm 0.67$ and $1.19 \pm 0.43$ for 
a

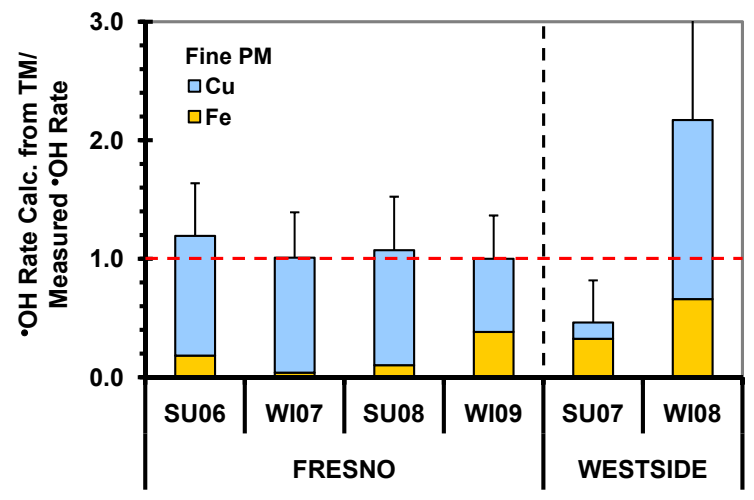

b

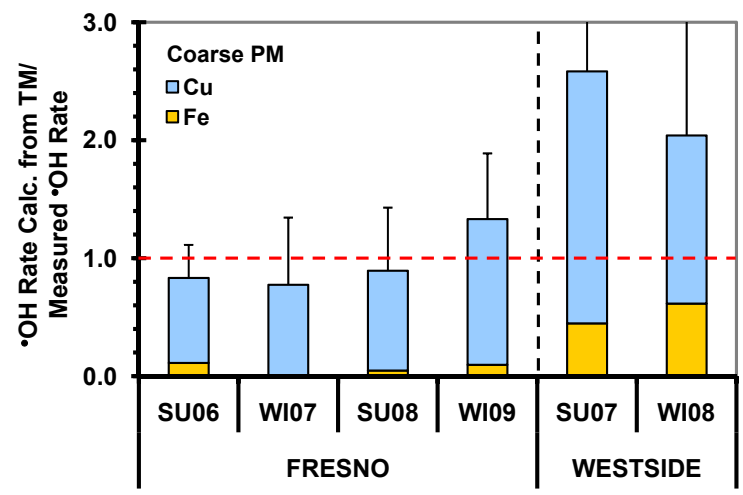

Fig. 9. Contributions of SLF-soluble $\mathrm{Cu}$ (blue bars) and Fe (yellow bars) to the initial rate of ${ }^{\bullet} \mathrm{OH}$ generation in SLF with Asc in fine (a) and coarse (b) particles. Values are means $\pm \mathrm{SD}, n=3$. There are three samples whose error bars extend beyond the range of the $\mathrm{y}$-axis (mean $\pm 1 \mathrm{SD}$ ): Westside winter 2008 fine PM, 2.2 \pm 1.9 ; Westside summer 2007 coarse PM, 2.6 \pm 3.1 ; Westside winter 2008 coarse PM, $2.0 \pm 2.0$.

the maximum ${ }^{\bullet} \mathrm{OH}$, respectively. For the Westside samples, $\mathrm{Fe}$ and $\mathrm{Cu}$ can also account for measured ${ }^{\bullet} \mathrm{OH}$ generation, although the results are quite noisy: the average sum of ratios for the Westside fine and coarse PM are $1.3 \pm 1.1$ and $2.3 \pm 2.6$ for the rate of ${ }^{\bullet} \mathrm{OH}$ formation, and $1.4 \pm 0.7$ and $2.1 \pm 5.2$ for the maximum ${ }^{\bullet} \mathrm{OH}$, respectively. As we described previously, Fresno $\mathrm{PM}_{\mathrm{cf}}$ generally contains higher levels of PM-mass-normalized soluble copper (i.e. ng-Cu $\mu g^{-1}-\mathrm{PM}$ ) than the Fresno $\mathrm{PM}_{2.5}$ (Shen et al., 2011), which helps to explain why the Fresno coarse PM is generally more reactive in generating ${ }^{\bullet} \mathrm{OH}$ than the corresponding fine PM on a PM-mass-normalized basis (Fig. 3b, Fig. S1b).

Our current finding that soluble $\mathrm{Cu}$ can account for essentially all of ${ }^{\bullet} \mathrm{OH}$ generation from the Fresno $\mathrm{PM}_{2.5}$ is an interesting contrast to our previous finding that dissolved $\mathrm{Fe}$ dominates ${ }^{\bullet} \mathrm{OH}$ formation from $\mathrm{PM}_{2.5}$ collected in Davis,
CA (Vidrio et al., 2009). This difference is likely due to the fact that the SLF in Vidrio et al. study contained both ascorbate $(200 \mu \mathrm{M})$ and citrate $(300 \mu \mathrm{M})$, while the SLF in this work contained only ascorbate $(50 \mu \mathrm{M})$. We recently reported that, compared to an SLF containing only ascorbate, adding citrate enhances the ability of Fe to generate ${ }^{\bullet} \mathrm{OH}$ and inhibits the ability of $\mathrm{Cu}$ to make ${ }^{\bullet} \mathrm{OH}$ (Charrier and Anastasio, 2011). Thus the composition of SLF used to extract particles can significantly, and differentially, affect the roles of different transition metals in ${ }^{\circ} \mathrm{OH}$ generation.

More broadly, our finding that transition metals dominate - OH formation by the SJV PM adds support to the link between particulate transition metals and PM-induced adverse health effects that has been found by previous studies (Costa and Dreher, 1997; Donaldson et al., 2003; Valavanidis et al., 2008; Lippmann and Chen, 2009; Gerlofs-Nijland et al., 2009). Our finding that $\mathrm{Cu}$ is responsible for the majority of $\bullet \mathrm{OH}$ generation is also consistent with the particulate$\mathrm{Cu}$ mediated toxic effects found in numerous in vitro and in vivo studies, including ROS generation and oxidative stress, protein and DNA oxidative damage, inflammation and tissue injury (Shi et al., 2003; Gasser et al., 2009; Wallenborn et al., 2009; Rushton et al., 2010). Considering that our Fresno (urban) site is close to a major highway and multiple surface streets while the Westside (rural) site has very little nearby traffic, vehicular brake wear emissions, which contain relatively high copper concentrations (Gasser et al., 2009; Bukowiecki et al., 2009), are likely an important source of $\mathrm{Cu}$ in our PM samples.

\section{Implications and uncertainties}

To examine if the amounts of ${ }^{\bullet} \mathrm{OH}$ produced in aqueous extracts of SJV PM might be significant for human health, we first estimate the expected daily $\mathrm{PM}$-mediated ${ }^{\bullet} \mathrm{OH}$ load in the lung lining fluid based on our measured maximum ${ }^{\bullet} \mathrm{OH}$ levels, using the procedure of Vidrio et al. (2009):

$\bullet \mathrm{OH} \operatorname{load}\left(\mathrm{nmol}^{\bullet} \mathrm{OH} \mathrm{d} \mathrm{d}^{-1}\right)=$ Maximum ${ }^{\bullet} \mathrm{OH}$ produced per air volume $\left(\mathrm{nmol}{ }^{\bullet} \mathrm{OH} \mathrm{\textrm {m } ^ { - 3 }}\right) \times$ Volume of air inhaled $\left(\mathrm{m}^{3} \mathrm{~d}^{-1}\right)$ $\times$ Fraction of inhaled PM that are deposited

Using the average of the maximum ${ }^{\bullet} \mathrm{OH}$ production over the $24 \mathrm{~h}$ extraction $\left(4.0 \mathrm{nmol} \mathrm{m}^{-3}\right.$ for $\mathrm{PM}_{2.5}$ and $0.7 \mathrm{nmol} \mathrm{m}^{-3}$ for $\mathrm{PM}_{\mathrm{cf}}$; Fig. S1), an inhaled air volume of $20 \mathrm{~m}^{3}$ per day, and assuming $30 \%$ of inhaled $\mathrm{PM}_{2.5}$ and $70 \%$ of inhaled $\mathrm{PM}_{\mathrm{cf}}$ deposit in lungs (Sarangapani and Wexler, 2000), we calculate that the average ${ }^{\bullet} \mathrm{OH}$ lung burden from aerosol inhalation is $34 \mathrm{nmol}^{\bullet} \mathrm{OH} \mathrm{d}^{-1}$ in Fresno, with $71 \%$ of $\bullet \mathrm{OH}$ formation from $\mathrm{PM}_{2.5}$. The same calculation for the Westside particles produces an average ${ }^{\bullet} \mathrm{OH}$ lung burden of $16 \mathrm{nmol}^{\bullet} \mathrm{OH} \mathrm{d}{ }^{-1}$, with $73 \%$ of ${ }^{\bullet} \mathrm{OH}$ formation from $\mathrm{PM}_{2.5}$. For individual samples, particle-mediated ${ }^{\bullet} \mathrm{OH}$ burdens in lung lining fluid range from 26 to 50 and 11 to $19 \mathrm{nmol} \mathrm{d}^{-1}$ for Fresno and Westside PM, respectively. 
Since lung lining fluid antioxidants provide an important defense network to protect against ${ }^{\bullet} \mathrm{OH}$-mediated cellular damage, we compare the estimated ${ }^{\bullet} \mathrm{OH}$ burdens to the total amount of antioxidants in lung lining fluid, which is approximately $15000 \mathrm{nmol}$ (Vidrio et al., 2008). Since the total antioxidant level is much higher than the levels of PM-mediated - $\mathrm{OH}$ from the Fresno and Westside particles, the amounts of - $\mathrm{OH}$ generated might not be significant for human health. Even peak $\mathrm{PM}_{2.5}$ events in Fresno likely produce relatively low amounts of $\bullet \mathrm{OH}$. For example, the maximum $24 \mathrm{~h}$ average $\mathrm{PM}_{2.5}$ concentration was $\sim 100 \mu \mathrm{g} \mathrm{m}^{-3}$ in both 2006 and 2007 (California Air Resources Board, 2010), which is 3 times higher than our average Fresno $\mathrm{PM}_{2.5}$ concentration $\left(33 \mu \mathrm{g} \mathrm{m}^{-3}\right)$ (Shen et al., 2011). Assuming a linear response between $\mathrm{PM}_{2.5}$ mass and ${ }^{\bullet} \mathrm{OH}$ generation, this peak $\mathrm{PM}_{2.5}$ level corresponds to a daily ${ }^{\bullet} \mathrm{OH}$ burden in the lung lining fluid of $\sim 70 \mathrm{nmol}$, which is still quite small compared to the antioxidant pool. However, relatively small amounts of - $\mathrm{OH}$ can lead to much greater levels of ROS, and oxidative damage, in vivo by initiating lipid peroxidation (Leibovitz and Siegel, 1980). In addition, additional ROS - including ${ }^{\bullet} \mathrm{OH}$, will be formed indirectly by PM via activation of oxidant-dependent signaling pathways in lung epithelial cells (Gonzalez-Flecha, 2004). Furthermore, other ambient air pollutants, such as ozone, can act additively or synergistically with $\mathrm{PM}$ to increase aqueous-phase ${ }^{\bullet} \mathrm{OH}$ production at physiological pH (Valavanidis et al., 2009).

While our results suggest that the chemical generation of - OH by inhaled ambient particles might lead to toxic effects under some circumstances, there are some large uncertainties. First, our results are for cell-free solutions that do not include biological responses that either increase (e.g. PMmediated generation of ROS by activated macrophages and epithelial cells) or decrease (e.g. decomposition of ${ }^{\bullet} \mathrm{O}_{2}^{-}$and $\mathrm{HOOH}$ by superoxide dismutase and catalase, respectively) cellular oxidative stress. Secondly, while we only included one antioxidant (ascorbate) in our surrogate lung fluid for PM extraction, recent studies suggest that other antioxidants (e.g. glutathione) and endogenous substances (e.g. citrate) in lung fluid can effectively inhibit the generation of $\bullet \mathrm{OH}$ by $\mathrm{Cu}$, while increasing ${ }^{\bullet} \mathrm{OH}$ from $\mathrm{Fe}$ (Vidrio et al., 2008; Charrier and Anastasio, 2011). Lastly, because the $50 \mu \mathrm{M}$ of ascorbate used in our PM extraction solution is at the lower end of human lung lining fluid Asc levels (Cross et al., 1994; van der Vliet et al., 1999), we expect more ${ }^{\bullet} \mathrm{OH}$ production at higher ascorbate concentrations.

\section{Conclusions}

We have quantified the formation of ${ }^{\bullet} \mathrm{OH}$ in cell-free aqueous extracts of PM from an urban and rural site in the San Joaquin Valley of California. Although the sample size is small, our results show that: (1) in general, the urban (Fresno) samples generate more ${ }^{\bullet} \mathrm{OH}$ than the rural (Westside) samples;
(2) normalized by air volume, the fine PM generally makes more ${ }^{\bullet} \mathrm{OH}$ than the corresponding coarse PM; (3) normalized by PM mass, the coarse PM typically generates more - $\mathrm{OH}$ than the fine PM; (4) the presence of a physiologically relevant level of ascorbate in the extraction solution greatly enhances the formation of $\bullet \mathrm{OH}$, and (5) transition metals, especially SLF-soluble $\mathrm{Cu}$, play a dominant role in ${ }^{\bullet} \mathrm{OH}$ generation from the SJV PM. While it is difficult to extrapolate from our acellular results to possible in vivo effects, an estimate of the lung lining fluid ${ }^{\bullet} \mathrm{OH}$ burden suggests that ${ }^{\bullet} \mathrm{OH}$ generation from inhaled particles could potentially cause toxicity at high particle levels.

\section{Supplementary material related to this article is available online at: http://www.atmos-chem-phys.net/11/9671/2011/ acp-11-9671-2011-supplement.pdf.}

Acknowledgements. We thank Yongjing Zhao, Walter Ham, Mike Kleeman, Chris Ruehl, Norman Kado and Yuee Pan for PM samples. This research was funded by the US Environmental Protection Agency (EPA) through grant number RD-83241401-0 to the San Joaquin Valley Aerosol Health Effects Research Center at the University of California, Davis. Additional funding was provided by the California Agricultural Experiment Station (Project CA-D*-LAW-6403-RR) and Award Number P42ES004699 from the National Institute of Environmental Health Sciences (NIEHS). The contents are solely the responsibility of the authors and do not necessarily represent the official views of the EPA, the NIEHS, or the National Institutes of Health.

Edited by: T. Bertram

\section{References}

Alaghmand, M. and Blough, N. V.: Source-dependent variation in hydroxyl radical production by airborne particulate matter, Environ. Sci. Technol., 41, 2364-2370, 2007.

Anastasio, C. and McGregor, K. G.: Chemistry of fog waters in California's Central Valley: 1. In situ photoformation of hydroxyl radical and singlet molecular oxygen, Atmos. Environ., 35, 1079-1089, 2001.

Baulig, A., Poirault, J. J., Ausset, P., Schins, R., Shi, T. M., Baralle, D., Dorlhene, P., Meyer, M., Lefevre, R., Baeza-Squiban, A., and Marano, F.: Physicochemical characteristics and biological activities of seasonal atmospheric particulate matter sampling in two locations of Paris, Environ. Sci. Technol., 38, 5985-5992, 2004.

Bektasoglu, B., Ozyurek, M., Guclu, K., and Apak, R.: Hydroxyl radical detection with a salicylate probe using modified CUPRAC spectrophotometry and HPLC, Talanta, 77, 90-97, 2008.

Bukowiecki, N., Lienemann, P., Hill, M., Figi, R., Richard, A., Furger, M., Rickers, K., Falkenberg, G., Zhao, Y. J., Cliff, S. S., Prevot, A. S. H., Baltensperger, U., Buchmann, B., and Gehrig, R.: Real-world emission factors for antimony and other brake wear related trace elements: size-segregated values for light 
and heavy duty vehicles, Environ. Sci. Technol., 43, 8072-8078, 2009.

Buxton, G. V., Greenstock, C. L., Helman, W. P., and Ross, A. B.: Critical-review of rate constants for reactions of hydrated electrons, hydrogen-atoms and hydroxyl radicals $\left({ }^{\bullet} \mathrm{OH} /{ }^{\bullet} \mathrm{O}^{-}\right)$in aqueous-solution, J. Phys. Chem. Ref. Data, 17, 513-886, 1988.

California Air Resources Board: The California almanac of emissions and air quality - 2009 edition, available at: http://www.arb. ca.gov/aqd/almanac/almanac09/almanac09.htm, 2010.

Charrier, J. G. and Anastasio, C.: Impacts of antioxidants on hydroxyl radical production from individual and mixed transition metals in a surrogate lung fluid, Atmos. Environ., in press, 2011.

Cohn, C. A., Simon, S. R., and Schoonen, M. A. A.: Comparison of fluorescence-based techniques for the quantification of particle-induced hydroxyl radicals, Part. Fibre Toxicol., 5, 2, doi:10.1186/1743-8977-5-2, 2008.

Costa, D. L., and Dreher, K. L.: Bioavailable transition metals in particulate matter mediate cardiopulmonary injury in healthy and compromised animal models, Environ. Health Perspect., 105, 1053-1060, 1997.

Cross, C. E., Vandervliet, A., Oneill, C. A., Louie, S., and Halliwell, B.: Oxidants, antioxidants, and respiratory-tract lining fluids, Environ. Health Perspect., 102, 185-191, 1994.

Dellinger, B., Pryor, W. A., Cueto, R., Squadrito, G. L., Hegde, V., and Deutsch, W. A.: Role of free radicals in the toxicity of airborne fine particulate matter, Chem. Res. Toxicol., 14, 13711377, 2001

DiStefano, E., Eiguren-Fernandez, A., Delfino, R. J., Sioutas, C., Froines, J. R., and Cho, A. K.: Determination of metal-based hydroxyl radical generating capacity of ambient and diesel exhaust particles, Inhal. Toxicol., 21, 731-738, 2009.

Dockery, D. W., Pope, C. A., 3rd, Xu, X., Spengler, J. D., Ware, J. H., Fay, M. E., Ferris Jr., B. G., and Speizer, F. E.: An association between air pollution and mortality in six U.S. cities, N. Engl. J. Med., 329, 1753-1759, 1993.

Donaldson, K., Brown, D. M., Mitchell, C., Dineva, M., Beswick, P. H., Gilmour, P., and MacNee, W.: Free radical activity of PM10: iron-mediated generation of hydroxyl radicals, Environ. Health Perspect., 105, 1285-1289, 1997.

Donaldson, K., Stone, V., Borm, P. J., Jimenez, L. A., Gilmour, P. S., Schins, R. P., Knaapen, A. M., Rahman, I., Faux, S. P., Brown, D. M., and MacNee, W.: Oxidative stress and calcium signaling in the adverse effects of environmental particles $\left(\mathrm{PM}_{10}\right)$, Free Radic. Biol. Med., 34, 1369-1382, 2003.

Forman, H. J., Maiorino, M., and Ursini, F.: Signaling functions of reactive oxygen species, Biochemistry, 49, 835-842, 2010.

Gasser, M., Riediker, M., Mueller, L., Perrenoud, A., Blank, F., Gehr, P., and Rothen-Rutishauser, B.: Toxic effects of brake wear particles on epithelial lung cells in vitro, Part. Fibre Toxicol., 6, 30, doi:10.1186/1743-8977-6-30, 2009.

Gerlofs-Nijland, M. E., Rummelhard, M., Boere, A. J. F., Leseman, D., Duffin, R., Schins, R. P. F., Borm, P. J. A., Sillanpaa, M., Salonen, R. O., and Cassee, F. R.: Particle induced toxicity in relation to transition metal and polycyclic aromatic hydrocarbon contents, Environ. Sci. Technol., 43, 4729-4736, 2009.

Ghio, A. J., Stonehuerner, J., Dailey, L. A., and Carter, J. D.: Metals associated with both the water-soluble and insoluble fractions of an ambient air pollution particle catalyze an oxidative stress, Inhal. Toxicol., 11, 37-49, 1999.
Gonzalez-Flecha, B.: Oxidant mechanisms in response to ambient air particles, Mol. Aspects Med., 25, 169-182, 2004.

Held, K. D., Sylvester, F. C., Hopcia, K. L., and Biaglow, J. E.: Role of Fenton chemistry in thiol-induced toxicity and apoptosis, Radiat. Res., 145, 542-553, 1996.

Hetland, R. B., Refsnes, M., Myran, T., Johansen, B. V., Uthus, N., and Schwarze, P. E.: Mineral and/or metal content as critical determinants of particle-induced release of IL-6 and IL-8 from A549 cells, J. Toxicol. Environ. Health A, 60, 47-65, 2000.

Jimenez, L. A., Thompson, J., Brown, D. A., Rahman, I., Antonicelli, F., Duffin, R., Drost, E. M., Hay, R. T., Donaldson, K., and MacNee, W.: Activation of NF-kappaB by PM(10) occurs via an iron-mediated mechanism in the absence of IkappaB degradation, Toxicol. Appl. Pharmacol., 166, 101-110, 2000.

Jung, H., Guo, B., Anastasio, C., and Kennedy, I. M.: Quantitative measurements of the generation of hydroxyl radicals by soot particles in a surrogate lung fluid, Atmos. Environ., 40, 1043-1052, 2006.

Kell, D. B.: Towards a unifying, systems biology understanding of large-scale cellular death and destruction caused by poorly liganded iron: Parkinson's, Huntington's, Alzheimer's, prions, bactericides, chemical toxicology and others as examples, Arch. Toxicol., 84, 825-889, 2010.

Kennedy, T., Ghio, A. J., Reed, W., Samet, J., Zagorski, J., Quay, J., Carter, J., Dailey, L., Hoidal, J. R., and Devlin, R. B.: Copperdependent inflammation and nuclear factor-kappaB activation by particulate air pollution, Am. J. Respir. Cell Mol. Biol., 19, 366378, 1998

Knaapen, A. M., Shi, T., Borm, P. J., and Schins, R. P.: Soluble metals as well as the insoluble particle fraction are involved in cellular DNA damage induced by particulate matter, Mol. Cell. Biochem., 234-235, 317-326, 2002.

Kunzli, N., Mudway, I. S., Gotschi, T., Shi, T., Kelly, F. J., Cook, S., Burney, P., Forsberg, B., Gauderman, J. W., Hazenkamp, M. E., Heinrich, J., Jarvis, D., Norback, D., Payo-Losa, F., Poli, A., Sunyer, J., and Borm, P. J.: Comparison of oxidative properties, light absorbance, total and elemental mass concentration of ambient $\mathrm{PM}_{2.5}$ collected at 20 European sites, Environ. Health Perspect., 114, 684-690, 2006.

Leibovitz, B. E. and Siegel, B. V.: Aspects of free-radical reactions in biological-systems - aging, J. Gerontol., 35, 45-56, 1980.

Li, N., Hao, M., Phalen, R. F., Hinds, W. C., and Nel, A. E.: Particulate air pollutants and asthma. A paradigm for the role of oxidative stress in PM-induced adverse health effects, Clin. Immunol., $109,250-265,2003$.

Li, N., Xia, T., and Nel, A. E.: The role of oxidative stress in ambient particulate matter-induced lung diseases and its implications in the toxicity of engineered nanoparticles, Free Radic. Biol. Med., 44, 1689-1699, 2008.

Lippmann, M. and Chen, L. C.: Health effects of concentrated ambient air particulate matter (CAPs) and its components, Crit. Rev. Toxicol., 39, 865-913, 2009.

McGregor, G. P. and Biesalski, H. K.: Rationale and impact of vitamin $\mathrm{C}$ in clinical nutrition, Curr. Opin. Clin. Nutr. Metab. Care, 9, 697-703, 2006

Nawrot, T. S., Kuenzli, N., Sunyer, J., Shi, T. M., Moreno, T., Viana, M., Heinrich, J., Forsberg, B., Kelly, F. J., Sughis, M., Nemery, B., and Borm, P.: Oxidative properties of ambient $\mathrm{PM}_{2.5}$ and elemental composition: Heterogeneous associations in 19 European 
cities, Atmos. Environ., 43, 4595-4602, 2009.

Pekkanen, J., Peters, A., Hoek, G., Tiittanen, P., Brunekreef, B., de Hartog, J., Heinrich, J., Ibald-Mulli, A., Kreyling, W. G., Lanki, T., Timonen, K. L., and Vanninen, E.: Particulate air pollution and risk of ST-segment depression during repeated submaximal exercise tests among subjects with coronary heart disease: the exposure and risk assessment for fine and ultrafine particles in ambient air (ULTRA) study, Circulation, 106, 933-938, 2002.

Pope, C. A. and Dockery, D. W.: Health effects of fine particulate air pollution: lines that connect, J. Air Waste Manage. Assoc., 56, 709-742, 2006.

Pope, C. A. III, Bates, D. V., and Raizenne, M. E.: Health effects of particulate air pollution: time for reassessment?, Environ. Health Perspect., 103, 472-480, 1995.

Pope, C. A., Burnett, R. T., Thurston, G. D., Thun, M. J., Calle, E. E., Krewski, D., and Godleski, J. J.: Cardiovascular mortality and long-term exposure to particulate air pollution - epidemiological evidence of general pathophysiological pathways of disease, Circulation, 109, 71-77, 2004.

Prahalad, A. K., Soukup, J. M., Inmon, J., Willis, R., Ghio, A. J., Becker, S., and Gallagher, J. E.: Ambient air particles: effects on cellular oxidant radical generation in relation to particulate elemental chemistry, Toxicol. Appl. Pharmacol., 158, 81-91, 1999.

Prahalad, A. K., Inmon, J., Dailey, L. A., Madden, M. C., Ghio, A. J., and Gallagher, J. E.: Air pollution particles mediated oxidative DNA base damage in a cell free system and in human airway epithelial cells in relation to particulate metal content and bioreactivity, Chem. Res. Toxicol., 14, 879-887, 2001.

Rodriguez, C. E., Fukuto, J. M., Taguchi, K., Froines, J., and Cho, A. K.: The interactions of 9,10-phenanthrenequinone with glyceraldehyde-3-phosphate dehydrogenase (GAPDH), a potential site for toxic actions, Chem.-Biol. Interact., 155, 97-110, 2005.

Rushton, E. K., Jiang, J., Leonard, S. S., Eberly, S., Castranova, V., Biswas, P., Elder, A., Han, X. L., Gelein, R., Finkelstein, J., and Oberdorster, G.: Concept of assessing nanoparticle hazards considering nanoparticle dosemetric and chemical/biological response metrics, J. Toxicol. Environ. Health A, 73, 445-461, 2010.

Sarangapani, R. and Wexler, A. S.: The role of dispersion in particle deposition in human airways, Toxicol. Sci., 54, 229-236, 2000.

Satoh, K. and Sakagami, H.: Effect of metal ions on radical intensity and cytotoxic activity of ascorbate, Anticancer Res., 17, 1125-1129, 1997.

Schaumann, F., Borm, P. J., Herbrich, A., Knoch, J., Pitz, M., Schins, R. P., Luettig, B., Hohlfeld, J. M., Heinrich, J., and Krug, N.: Metal-rich ambient particles (particulate matter 2.5) cause airway inflammation in healthy subjects, Am. J. Respir. Crit. Care Med., 170, 898-903, 2004.
Shen, H. and Anastasio, C.: A comparison of hydroxyl radical and hydrogen peroxide generation in ambient particle extracts and laboratory metal solutions, Atmos. Environ., submitted, 2011.

Shen, H., Barakat, A. I., and Anastasio, C.: Generation of hydrogen peroxide from San Joaquin Valley particles in a cell-free solution, Atmos. Chem. Phys., 11, 753-765, doi:10.5194/acp-11753-2011, 2011.

Shi, T., Knaapen, A. M., Begerow, J., Birmili, W., Borm, P. J., and Schins, R. P.: Temporal variation of hydroxyl radical generation and 8-hydroxy-2'-deoxyguanosine formation by coarse and fine particulate matter, Occup. Environ. Med., 60, 315-321, 2003.

Stadtman, E. R.: Ascorbic acid and oxidative inactivation of proteins, Am. J. Clin. Nutr., 54, 1125S-1128S, 1991.

Valavanidis, A., Fiotakis, K., and Vlachogianni, T.: Airborne particulate matter and human health: toxicological assessment and importance of size and composition of particles for oxidative damage and carcinogenic mechanisms, J. Environ. Sci. Health C Environ. Carcinog. Ecotoxicol. Rev., 26, 339-362, 2008.

Valavanidis, A., Loridas, S., Vlahogianni, T., and Fiotakis, K.: Influence of ozone on traffic-related particulate matter on the generation of hydroxyl radicals through a heterogeneous synergistic effect, J. Hazard. Mater., 162, 886-892, 2009.

van der Vliet, A., O'Neill, C. A., Cross, C. E., Koostra, J. M., Volz, W. G., Halliwell, B., and Louie, S.: Determination of lowmolecular-mass antioxidant concentrations in human respiratory tract lining fluids, Am. J. Physiol., 276, L289-296, 1999.

Vidrio, E., Jung, H., and Anastasio, C.: Generation of hydroxyl radicals from dissolved transition metals in surrogate lung fluid solutions, Atmos. Environ., 42, 4369-4379, 2008.

Vidrio, E., Phuah, C. H., Dillner, A. M., and Anastasiot, C.: Generation of hydroxyl radicals from ambient fine particles in a surrogate lung fluid solution, Environ. Sci. Technol., 43, 922-927, 2009.

Wallenborn, J. G., Schladweiler, M. J., Richards, J. H., and Kodavanti, U. P.: Differential pulmonary and cardiac effects of pulmonary exposure to a panel of particulate matter-associated metals, Toxicol. Appl. Pharmacol., 241, 71-80, 2009.

Walling, C., Eltaliaw, G. M., and Johnson, R. A.: Fentons reagent.4. structure and reactivity relations in reactions of hydroxyl radicals and redox reactions of radicals, J. Am. Chem. Soc., 96, 133-139, 1974.

Wang, Y., Arellanes, C., Curtis, D. B., and Paulson, S. E.: Probing the source of hydrogen peroxide associated with coarse mode aerosol particles in Southern California, Environ. Sci. Technol., 44, 4070-4075, 2010.

Zepp, R. G., Faust, B. C., and Hoigne, J.: Hydroxyl radical formation in aqueous reactions ( $\mathrm{pH} 3-8$ ) of iron(II) with hydrogenperoxide - the photo-fenton reaction, Environ. Sci. Technol., 26, 313-319, 1992. 